to the rest of the book. Certain subjects, such as the detection and measurement of the radiations, are excluded on the very reasonable grounds that numerous alternative texts are available covering these fields. He confines his attention to certain selected fields, but as in his consideration of accelerators, for example, the treatment is often very superficial. Target preparations, beam monitoring and range measurements are included, but only the briefest of discussion proves possible. One can readily sympathize with the author in his quandary regarding the proper course to choose in this chapter, but in its present form it is distinctly disappointing.

The final chapter deals with applications of nuclear chemistry and includes brief accounts of a number of topies, sometimes only tenuously connected with the main theme of the book. Again it might have been better to have excluded topics such as Mössbauer spectrometry and reactors, that cannot adequately be considered, and left more space for more closely related topics such as nucleogenesis and cosmic nuclear processes.

It is because the earlier chapters are good and the treatment satisfactory, however, that the reader is the more critical of these final two chapters.

A. G. MADDOCK

\section{SPACECRAFT RETURN}

\section{Atmospheric Re-entry}

An Introduction to its Science and Engineering. By John J. Martin. (Prentice-Hall International Series in Space Technology.) Pp. xxi + 264. (Englewood Cliffs, N.J.: PrenticeHall, Inc., 1966.) n.p.

DEspite the title, this book is written much more from the point of view of the physicist than that of the engineer. Engineering aspects of re-entry phenomena are discussed either cursorily or not at all. Structural design is largely ignored apart from some discussions of heat sinks and there is no discussion of vehicle control problems. The treatment also seems heavily biased towards the ballistic missile as against other types of space vehicle; presumably this derives from the author's association with the U.S. ICBM programme.

The book's chief merit is the very lucid summary in Chapters 5-7 of present knowledge of the flow field around a re-entering body, the associated chemical kinetics and the implications for heat transfer into the body and also the electro-magnetic radiation. A point of criticism is that in the discussion of heat transfer rates an impression is given that the transition point from laminar to turbulent boundary layer flow can be predicted with some confidence using as criterion Reynolds number based on momentum boundary layer thickness; the engineering reader should bo warned of the hazards of this undertaking. This is a minor blemish, however, and these chapters are valuable to any student of missile or spacecraft technology.

The rest of the book is not to quite the same standard. It is mainly an introduction to the kinematies and dynamics of long-range missiles; approximate solutions for special cases of the equations of motion are used to illustrate the significance of various parameters. Discussion of dynamic motion concentrates on the axisymmetric body; stability criteria are described and there is some analysis of the influence on range errors of factors such as trim and rate of roll, but without any indication of how they may be modified. There is a disappointingly brief examination of the kinematics of lifting re-entry.

The last chapter stands rather apart from the others and is an outline of some methods useful in the schematic design and system analysis of re-entry projects. The examples worked are all of axi-symmetric bodies and military aspects are emphasized, but the methods used are of wider interest.
The book is illustrated with a large number of diagrams, and the chapter reference lists are excellent. It can be recommended for use in advanced courses on missile or spacecraft technology.

R. H. Francis

\section{URANIUM ORES OF FRANCE}

\section{Les Minerais Uranifères Français}

Tome Trois, Deuxième Volume. Publié sous la direction de Marcel Roubault. (Bibliothèque des Sciences et Techniques Nucléaires.) Pp. 354. (Saclay, S. et O. : Institut National des Sciences et Techniques Nucléaires : Paris : Presses Universitaires de France, 1965.) n.p.

No uranium deposits of economic significance were known in metropolitan France when the geologists and prospectors of the Commissariat à l'Energie Atomique began their field investigations two decades ago. To-day, however, the established French reserves of ore far surpass the proven potentiality of all the rest of Europe. The first volume of Les Minerais Uraniferes Français, published in 1960, contained an illuminating account of the mineralogy of these important ores ; and in volumes II and III (1), regional geological descriptions of the several groups of lode deposits were made available. The final part, III (2), of this series of monographs deals with stratified or "strata-bound" deposits, most of which have been discovered quite recently. Apart from many hundreds of minor occurrences these fall into four main groups. Westphalian shales in the St. Hippolyte coal basin of the Vosges, which unconformably underlie Stephanian sandstones and occupy a basin floored by granite, are mineralized to a tenor of between 0.01 and (locally) 6.6 per cent uranium, accompanied by sulphides, the best ore being found in the centre of shale wedges in sandstone. Upwards of four million tons of this mineralization has been blocked out, much of it of good grade. In the Massif Central the presence of some thousands of tons of uranium metal, in sub-marginal ore with about $0.02-0.03$ per cent uranium, has been established in passage beds between Stephanian and Autunian, disseminated in sandstones as vanadates (francevillite and carnotite) and phosphates (autunite), often with radioactive hydroearbon. In the department of Herrault in the Cévennes, Permian arkoses and bituminous shales are impregnated with pitchblende, radioactive hydrocarbon and secondary minerals, the ores occurring both along fault zones and as stratiform bodies. Most remarkable of all, numerous small patches of Oligocene sands in Cantal, occupying basins in granite, are mineralized to varying degrees by vanadates and phosphates. The most important of these is a tiny basin discovered in 1957 at St. Pierre, where a 20 metre thickness of sands contains about 1,100 tons of uranium in ore of about $0 \cdot 3$ per cent grade. This has given rise to the only open-cast uranium mine in Europe, which yielded 400 tons (metal content) up to 1963 . The origin of these surprising deposits is much debated, but there seems good reason to believe that like the very large contemporary discoveries in Wyoming the ores have been precipitated from groundwaters percolating downwards which acquired their uranium by leaching overlying strata. The French reports merit widespread eirculation both as an aid to prospecting elsewhere and as a contribution to a better understanding of ore-forming processes.

C. F. DAVIDSON

\section{EUROPEAN MAMMALS}

The Terrestrial Mammals of Western Europe

By G. B. Corbet. Pp. xi $+264+15$ plates. G. T. Foulis and Co., Ltd., 1966.) 56s. net.

(London:

During the past decade there has been a great increase of interest in the study of mammals in the British Isles. 